\title{
Targeting beta-cell preservation in the management of type 2 diabetes
}

\author{
CHARLOTTE K BOUGHTON, ${ }^{1}$ NEIL MUNRO, ${ }^{3}$ MARTIN WHYTEE ${ }^{2,3}$
}

\begin{abstract}
Type 2 diabetes (T2D) is widely considered a chronic and progressive disease without cure. As beta-cell function progressively declines over time, blood glucose rises. Current management of T2D involves incremental introduction of dietary and drug therapies to achieve normoglycaemia. However, recent studies have demonstrated remission of T2D following bariatric surgery, very low calorie diet or intensive insulin therapy, raising the possibility that the declining beta-cell function in T2D may be arrested or even reversed. The point at which such interventions are introduced in the course of T2D is key for clinical benefit. Future treatment strategies should be revised to target early betacell preservation and thus disease remission. This article reviews the pathogenesis of beta-cell dysfunction and evidence for the clinical benefit of preserving beta-cell function in T2D, and discusses the evidence for beta-cell preservation of current glucose-lowering therapies with particular reference to their effect when initiated at the time of diagnosis of T2D.

Br J Diabetes 2017;17:134-144
\end{abstract}

Key words: type 2 diabetes (T2D), beta-cell function, remission

\section{Introduction}

Type 2 diabetes (T2D) is widely considered a chronic progressive disease with no disease-modifying treatment or cure. Over time, blood glucose rises despite treatment escalation, as beta-cell function progressively declines. ${ }^{1}$ However, more recently, studies demonstrating restoration of normoglycaemia following bariatric surgery, very low-calorie diet (VLCD) or intensive insulin therapy (IIT) have raised the possibility that declining beta-cell function in T2D may be arrested or reversed. ${ }^{2-4}$

Department of Diabetes, King's College Hospital NHS Foundation Trust, London, UK

2 Department of Medicine, King's College Hospital NHS Foundation Trust, London, UK

Department of Clinical \& Experimental Medicine, University of Surrey, UK

Address for correspondence: $\mathrm{Dr}$ Charlotte Boughton Department of Diabetes, King's College Hospital, Denmark Hill, London SE5 9RS, UK

Tel: 02032999000

Fax: 02032996472

E-mail: charlotte.boughton@nhs.net

https://doi.org/10.15277/bjd.2017.148
This article reviews the pathogenesis of beta-cell dysfunction and evidence for the clinical benefit of preserving beta-cell function in T2D. We then discuss the evidence for beta-cell preservation of current glucose-lowering therapies, with particular reference to their effect when initiated at the time of diagnosis of T2D.

\section{Current diabetes management and challenges}

The goals of T2D management are to ameliorate the symptoms of hyperglycaemia and reduce the incidence of micro- and macrovascular complications. Current practice is to introduce glucose-lowering therapy in a stepwise fashion: lifestyle intervention followed by oral agents or glucagon-like peptide-1 (GLP-1) as monotherapy (then in combination), and finally insulin therapy. ${ }^{5}$ However, 34\% of individuals with T2D do not achieve glycaemic targets. ${ }^{6}$ Five years after diagnosis, only $5 \%$ of patients remain free from glucose-lowering medication and $50 \%$ of individuals require insulin therapy. ${ }^{7}$

\section{The beta-cell in the pathophysiology of T2D}

Development of T2D requires both insulin resistance in muscle and liver and impaired beta-cell insulin secretion, although the contribution of each can vary. An increased rate of adipocyte lipolysis, diminished gastrointestinal tract incretin release, hyperglucagonaemia, reduced renal glucose excretion and brain insulin sensitivity also play important roles in glucose intolerance. ${ }^{8}$ Individuals with normal glucose tolerance can have wide variation in insulin sensitivity, yet glucose tolerance remains normal through beta-cell hypersecretion. ${ }^{9}$ Transition from impaired glucose tolerance (IGT) to T2D occurs once beta-cells fail to compensate for insulin resistance. ${ }^{10}$

The proposed sequence of pathological events starts with energy excess causing increased hepatic fat, a process which is accelerated by peripheral insulin resistance causing hyperinsulinaemia. Increased hepatic fat causes hepatic insulin resistance with failure to suppress fasting glucose production. Exposure of the beta-cells to excess fatty acids derived from circulating and locally deposited triacylglycerol suppresses glucose-mediated insulin secretion. ${ }^{11}$

This decline in beta-cell function starts several years before the diagnosis of T2D; the Whitehall II study demonstrated gradually increasing fasting plasma glucose (FPG) levels for 10-12 years prior to diagnosis of T2D. ${ }^{12}$ This trajectory changes dramatically two years before diagnosis, reflecting acute beta-cell decompensation (Figure 1).

A continuum of stages of beta-cell dysfunction during progression to T2D have been described. Initial insulin hypersecretion to maintain normoglycaemia in the face of insulin resistance is followed by a stable state of beta-cell adaptation to a slightly elevated 
Figure 1. Change in fasting plasma glucose prior to the onset of type 2 diabetes

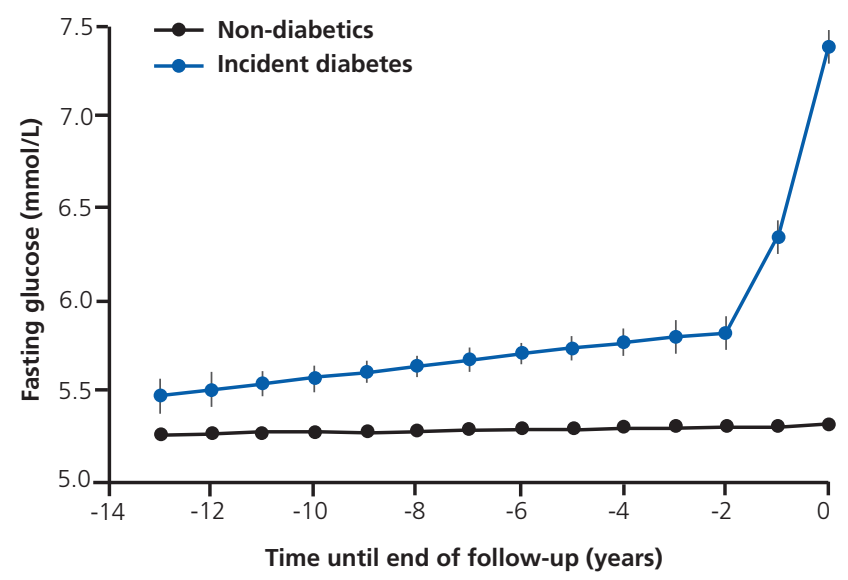

Reproduced with permission from Tabak et al. ${ }^{12}$

glucose level with diminished glucose-stimulated insulin secretion (GSIS). Early decompensation leading to rapid elevation in glucose levels is then followed by a stable decompensation phase. Finally, there is severe decompensation representing profound beta-cell failure. ${ }^{13}$ Crucially, movement between stages 1 to 4 can be in either direction, highlighting the potential for regaining normal beta-cell function. Reducing demand on beta-cells (beta-cell rest) can improve insulin secretion and beta-cell viability. ${ }^{14}$

At diagnosis of T2D, 50\% of beta-cell function has already been lost. ${ }^{15}$ Further loss is responsible for disease progression as the level of insulin resistance remains unchanged. ${ }^{16}$ Beta-cells are most metabolically stressed and vulnerable to apoptosis during the period of persistent hyperglycaemia around the time of the clinical onset of diabetes. ${ }^{12}$ Restoration of normoglycaemia at this stage may protect beta-cell function for the long term.

\section{Mechanisms of beta-cell damage: targets for reversal}

Mechanisms for beta-cell dysfunction may include: glucotoxicity, lipotoxicity, oxidative stress, endoplasmic reticulum (ER) stress, inflammatory stress and amyloid formation. These factors often act in concert and, without correction, lead to reduced functional betacell mass. It is unclear whether beta-cell failure results from reduced beta-cell number or function; a recent rodent study demonstrated beta-cell dedifferentiation under metabolic stress and conversion into other endocrine cell types including alpha cells with associated hyperglucagonaemia. ${ }^{17}$

\section{Glucotoxicity}

Chronic exposure to hyperglycaemia impairs GSIS and insulin biosynthesis. ${ }^{18}$ As hyperglycaemia causes oxidative and ER stress, beta-cell desensitisation and exhaustion ensue, leading to irreversible damage (beta-cell glucotoxicity) and apoptosis. ${ }^{19}$ These deleterious effects can be reversed by attaining normoglycaemia: insulin secretion increases in cultured beta-cells when media con- taining supraphysiological glucose levels is switched to normoglycaemic media, reflecting recovery following relief of beta-cell exhaustion. ${ }^{20}$ The efficacy of this intervention hinges on achieving normoglycaemia before beta-cell apoptosis occurs - it is timedependent.

\section{Lipotoxicity}

Hypertriglyceridaemia increases peripheral insulin resistance, indirectly increasing beta-cell demand. The direct effect of prolonged islet exposure to free fatty acids is evidenced by impaired insulin gene expression and GSIS21 and beta-cell apoptosis. ${ }^{22}$ Lipotoxicity seldom occurs without hyperglycaemia: hyperglycaemia influences intracellular fatty acid metabolism, promoting the synthesis of cellular lipids which inhibit GSIS and insulin gene expression. ${ }^{23}$ The term 'glucolipotoxicity' describes the synergistic deleterious effects on the beta-cell.

\section{Oxidative and endoplasmic reticulum (ER) stress}

Deteriorating metabolic control results in beta-cell oxidative and ER stress. ${ }^{24}$ Beta-cells have low intrinsic antioxidant capacity, making them vulnerable to oxidative stress which then impairs insulin biosynthesis and secretion. ${ }^{25,26}$ Increased markers of oxidative stress are seen in serum and islets of individuals with T2D, and levels inversely correlate with the degree of insulin secretion. ${ }^{27}$ Although controversial, antioxidants may improve GSIS in IGT and T2D. 28,29

The ER in the beta-cell is the critical cellular compartment for insulin biosynthesis. ER stress occurs when accumulation of abnormal proinsulin triggers the unfolded protein response signalling cascade. ${ }^{30}$ This promotes beta-cell secretory dysfunction and, with chronicity, beta-cell apoptosis. ${ }^{31}$ Post-mortem pancreatic sections from patients with T2D show increased expression of genes associated with ER stress. ${ }^{31}$ ER size, a marker of ER stress, is twice as large in beta-cells from T2D patients compared with non-diabetic patients. ${ }^{32}$

\section{Inflammation}

Pancreatic islets from individuals with T2D are infiltrated with immune cells and have elevated levels of pro-inflammatory cytokines. ${ }^{33,34}$ Transcription factor NF-KB and pro-inflammatory cytokine interleukin (IL)-1 $\beta$ are both activated by hyperglycaemia and hyperlipidaemia and are associated with impaired beta-cell function. ${ }^{35,36}$ Treatment with anakinra, an IL-1 $\beta$ receptor antagonist, improved beta-cell secretory capacity in individuals with T2D. ${ }^{37}$

\section{Amyloid deposition}

Islet amyloid polypeptide (IAPP) aggregates to form pathological islet amyloid in T2D causing beta-cell dysfunction and death. ${ }^{38}$ In chronic hyperglycaemia and hyperlipidaemia, IAPP synthesis increases in parallel with insulin synthesis, and can reach threshold levels that allow formation of pro-apoptotic IAPP oligomers. ${ }^{39}$

\section{First-phase insulin release}

The normal insulin secretory response to glucose has a biphasic pattern (Figure 2). The first-phase response, essential in transitioning from fasting to fed states, suppresses postprandial hepatic glucose 
Figure 2. Schematic of the first and second phase insulin release from the beta-cell in response to hyperglycaemia

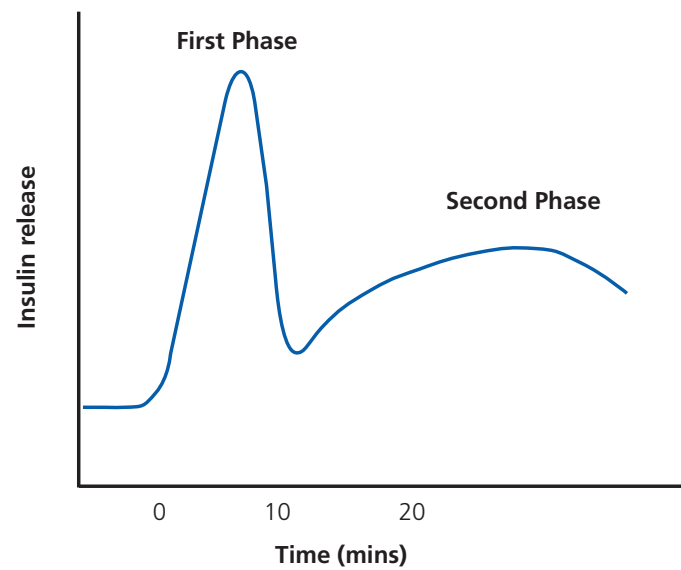

production and peripheral lipolysis. ${ }^{40}$ Within the beta-cell there are two functionally distinct pools of insulin secretory granules: a readily releasable pool containing $5 \%$ of the granules which accounts for first-phase secretion and a reserve pool containing the remaining $95 \%$ of granules accounting for the second phase. ${ }^{40}$

\section{Beta-cell dysfunction in T2D}

Attenuation of first-phase insulin secretion is the earliest detectable defect in beta-cell function. It can be seen in patients with IGT, ${ }^{41}$ in normoglycaemic women with a history of gestational diabetes ${ }^{42}$ and in normoglycaemic first-degree relatives of patients with T2D. ${ }^{43}$ The magnitude of first-phase insulin release inversely correlates with the degree of beta-cell dysfunction. The transition from normal glucose tolerance to T2D is associated with progressive deterioration in first-phase insulin secretion. ${ }^{10}$

Impaired first-phase release leads to postprandial hyperglycaemia (PPH) and increased risk of micro- and macrovascular complications. ${ }^{44}$ Restoration of prandial insulin, with subcutaneous insulin analogues, improves glucose tolerance in T2D. ${ }^{45}$ With diminished first-phase insulin secretion, plasma glucose rises causing beta-cell desensitisation and an augmented and sustained second-phase insulin release, characteristic of T2D. ${ }^{46}$

\section{Insulin deficiency}

Longitudinal cohort studies have shown a gradual reduction in circulating insulin despite persisting insulin resistance. ${ }^{15}$ Initially this may be masked by excess production of proinsulins. ${ }^{47}$ The rise in proinsulin represents increased insulin demand in T2D, causing depletion of mature insulin-rich granules with mobilisation of immature granules rich in proinsulin.

\section{Beta-cell apoptosis}

Post-mortem studies have shown that beta-cell number is reduced by $40 \%$ in patients with impaired fasting glucose (IFG) and $60 \%$ in T2D. ${ }^{48}$ Beta-cell mass decreases with duration of diabetes due to the increased rate of beta-cell apoptosis exceeding that of islet neogenesis and beta-cell replication - which remain relatively constant. ${ }^{48}$

\section{Loss of first-phase insulin response and cardiovascular (CV) risk}

$\mathrm{PPH}$ is associated with an increased incidence of CV and all-cause mortality, even in individuals without T2D.44,49 Interventions that preserve beta-cell function and restore first-phase response thereby attenuating $\mathrm{PPH}$ - theoretically could reduce CV events, although this has yet to be convincingly demonstrated in randomised controlled trials.

The HEART2D study found targeting PPH versus basal glucose in T2D after an acute myocardial infarction led to similar $\mathrm{HbA}_{1 \mathrm{c}}$ levels but no difference in the risk of CV events, 50 although post-hoc analyses suggested elderly patients may benefit. ${ }^{51}$ The NAVIGATOR study showed that, among patients with IGT plus CVD (or high risk for (VD), five years treatment with nateglinide to target PPH did not reduce CV events. ${ }^{52}$ The exception to these negative intervention studies has been the STOP-NIDDM trial in individuals with IGT: treatment with acarbose ( $\alpha$-glucosidase inhibitor that reduces $\mathrm{PPH}$ ) led to a $49 \%$ risk reduction in CV events. ${ }^{53}$

The UK Prospective Diabetes Study (UKPDS) showed a near linear relationship between $\mathrm{HbA}_{1 c}$ and macrovascular disease, but this trial targeted FPG rather than PPH. ${ }^{54}$ Conversely, the ORIGIN trial, using insulin glargine to target normal FPG for 6 years in people with early $\mathrm{T} 2 \mathrm{D}$ or prediabetes (IFG or IGT) and a high risk of CV events, found that fasting normoglycaemia did not affect CV outcomes. ${ }^{55}$

\section{Early intervention and the 'legacy effect'}

The UKPDS proved that glucose-lowering therapy with sulfonylureas or insulin lowered the risk of microvascular complications compared with dietary therapy. ${ }^{54}$ During the 10-year post-trial monitoring period there emerged significant risk reductions in myocardial infarction and all-cause mortality, despite no persisting difference in $\mathrm{HbA}_{1 \mathrm{c}}$ or glucose-lowering therapy between the groups. ${ }^{7}$ This persisting benefit, beyond the period of intensive intervention in early T2D, is the 'legacy effect'.

The Steno-2 study involved a multifactorial risk reduction programme in relatively young patients with T2D, of whom $25 \%$ were not taking diabetes medication at baseline. After 7.8 years, $\mathrm{HbA}_{1 \mathrm{c}}$ was $7.9 \%$ in the intervention arm and $9.0 \%$ in the control arm. The control group were then offered treatment intensification. After a further 5.5 years of follow-up, no difference in glycaemic control or other cardiovascular risk factors remained between the intensive and control arms. Even so, over 13.3 years of follow-up the intensively treated group had an absolute risk reduction of mortality of $20 \%$ (HR 0.54, 95\% Cl 0.32 to $0.89 ; p=0.02$ ) compared with conventional therapy. ${ }^{56}$

\section{Effect of later intensification}

Tight glycaemic control achieved only later may be disadvantageous. In three large randomised controlled studies, despite improved glycaemic control with intensive therapy, benefits in macrovascular events were not seen. ${ }^{57-59}$ 
In the ACCORD study, intensive therapy for 3.7 years increased mortality (HR 1.22, 95\% Cl 1.01 to 1.46; $p=0.04$ ) and did not reduce the incidence of major $\mathrm{CV}$ events.58 A five-year follow-up of intensive therapy suggested a reduced risk for the combined coronary endpoints of myocardial infarction, coronary revascularisation and unstable angina, 60 but this was offset by the earlier increased CV mortality. ${ }^{61}$ Nine-year follow-up data show a neutral overall effect on death and non-fatal CV events, but the increase in CV-related death, observed on earlier analyses, persists. ${ }^{62}$

In the VADT study, after 5.6 years of follow-up intensive glucose control in patients with poorly controlled T2D had no effect on the rates of $C V$ events or death. ${ }^{57}$

The ADVANCE study tested whether lowering $\mathrm{HbA}_{1 \mathrm{c}}$ to $6.5 \%$, using gliclazide plus other drugs, improved microvascular and macrovascular outcomes. After five years a $10 \%$ relative reduction was seen in combined major macrovascular and microvascular events, primarily due to a $21 \%$ relative reduction in nephropathy. ${ }^{59}$ After a further 5.4 years of follow-up from the end of the trial there was no legacy effect on macrovascular events. ${ }^{63}$

More prolonged follow-up may possibly be required to observe a legacy effect. Alternatively, patient characteristics may be responsible. In the UKPDS trial, patients were older (60-66 years), had a longer duration of diabetes (8-11.5 years) and greater macrovascular disease burden (30-46\%) than the younger, newly diagnosed patients. Benefits of intensive glycaemic control on macrovascular disease may only be seen if initiated early in the course of T2D. ${ }^{57} \mathrm{It}$ remains to be proven whether early recovery of first-phase insulin release is a component of macrovascular event reduction in these patients.

\section{Glycaemic remission}

Attainment of normoglycaemia, even if transient, shortly after diagnosis of T2D, may re-establish physiological beta-cell function and diet responsiveness for several years. ${ }^{3}$ Such an approach to the management of T2D avoids the glycaemic variability characteristic of the failing beta-cell as well as side-effects of chronic hypoglycaemic therapy or exogenous insulin such as weight gain and hypoglycaemia - themselves independent risk factors for CV disease.

Loss of first-phase insulin secretion is one of the earliest features of T2D and is associated with increased macrovascular disease risk and deteriorating beta-cell function. Early tight glycaemic control is an attractive prospect to mitigate or reverse these effects, although the evidence for clinical benefit remains uncertain.

\section{Effect of current glucose-lowering therapies on beta-cell preservation}

The management of T2D generally involves the progressive introduction of dietary and drug therapies to achieve normoglycaemia. Below we will discuss the evidence for beta-cell preservation of current glucose-lowering therapies, with particular reference to their effect on restoring first-phase insulin release when initiated at the time of diagnosis of T2D. It can be difficult to disentangle the effects of treatments on insulin resistance from those on beta-cell function. Some clinical studies have addressed this by a period of normoglycaemia prior to assessment of beta-cell function or by correcting improvements in beta-cell parameters for improvements in insulin sensitivity.

\section{Very low calorie diet (VLCD)}

The effects of VLCD ( $<800 \mathrm{kcal} /$ day) on T2D were first reported in the 1980s but have recently gained prominence with the potential for T2D remission. ${ }^{4,64}$

VLCD leads to a reduction in fasting plasma glucose within the first days - when weight loss is minimal - largely attributable to reduced hepatic glucose output.4,65 This is associated with reduced basal insulin secretion, suggesting improved hepatic insulin sensitivity. ${ }^{4,65}$ It would be predicted that reduction in FPG would improve beta-cell function by amelioration of glucotoxicity and, in overweight patients with T2D, eight weeks of VLCD can lead to a gradual restoration of first-phase insulin response. ${ }^{4,66}$

Reduced lipotoxicity following VLCD may also improve beta-cell function. A reduction in circulating free fatty acids (FFAs) and pancreatic triacylglycerol content has been observed with VLCD.4,66 Restoration of first-phase insulin secretion has been associated with reduced pancreatic fat, but no clear threshold exists relating pancreatic fat content to indices of insulin secretion, suggesting interindividual variance to 'tolerance' of pancreatic fat. ${ }^{4}$ The detrimental effect of pancreatic fat may be mediated by a threshold level of toxic metabolites rather than a dose response effect of stored triglycerides. ${ }^{4}$

VLCD for 4-8 weeks in obese individuals with T2D resulted in sustained improvements in glycaemia at 12-18 months, even in patients who regained body weight (although a less marked effect was evident in those with weight regain). ${ }^{67,68}$ Normoglycaemia was partly attributable to increased beta-cell insulin secretion in response to an oral glucose tolerance test (OGTT). ${ }^{68}$ Less durable effects have also been reported, with deterioration in glycaemic control within 12 months of VLCD. ${ }^{64,69}$ Baseline participant characteristics were similar between these studies, although the accompanying behavioural therapy programme varied.

Efficacy of VLCD is partly attributable to duration of T2D. VLCD for eight weeks achieved normoglycaemia (without other antidiabetic therapies) in $87 \%$ of individuals with a duration of diabetes $<4$ years compared with $50 \%$ of individuals with a longer duration of diabetes (>8 years). ${ }^{70}$ Other characteristics predicting a favourable response to VLCD were younger age, lower baseline FPG and higher fasting and first-phase insulin levels at diet initiation. These may reflect the importance of having salvageable beta-cell function at dietary onset. ${ }^{71}$

The optimal duration and timing of VLCD in T2D is unknown. The relative efficacy of VLCD in early T2D compared with other proposed beta-cell preserving therapies such as early IIT warrants study.

\section{Exercise}

The effect of exercise in improving glycaemia in individuals with T2D is well established, even without weight loss. ${ }^{72}$ However, the effect of exercise on restoring beta-cell function is less well understood. Studies have shown that exercise therapy for 12 weeks shortly after diagnosis improves insulin sensitivity and increases early insulin secretion in response to OGTT in overweight individuals with 
both IGT and T2D. ${ }^{73}$ The increased early insulin secretion remains significant even when corrected for improvements in insulin sensitivity observed after the intervention in those with T2D. ${ }^{74}$

In one study the beneficial effects of exercise training on betacell insulin secretion were only seen in individuals with T2D who had at least moderate beta-cell secretory capacity at baseline, suggesting an optimal timing of intervention..$^{75}$ Furthermore, exercise programmes were not able to normalise beta-cell function alone and many studies have combined exercise programmes with dietary interventions.

\section{Metformin}

Metformin inhibits hepatic glucose production and increases peripheral insulin sensitivity. In vitro studies suggest a directly protective effect of metformin on rat and human islets from glucotoxicity and lipotoxicity.76,77 In the UKPDS, patients with newly diagnosed T2D who received metformin had an initial increase in beta-cell function (assessed by HOMA) in the first year, but this subsequently declined at a similar rate to those treated with diet or sulphonylureas despite persistently increased insulin sensitivity with metformin. ${ }^{15}$ Similarly, the ADOPT (A Diabetes Outcome Progression Trial) study of recently diagnosed T2D patients showed a small early benefit of metformin on beta-cell function (in response to OGTT), followed by a slow decline - albeit less than those receiving sulphonylurea therapy - over four years..$^{78}$ Conversely, a recent study comparing 24 weeks of metformin to acarbose in overweight/obese Chinese patients with newly diagnosed T2D showed no significant effect of metformin therapy on early-phase insulin secretion following a mixed meal test. ${ }^{79}$

\section{Sulphonylureas}

Sulphonylureas stimulate insulin secretion by inhibiting the ATP-sensitive potassium channel which, following beta-cell depolarisation, results in exocytosis of insulin-containing granules. ${ }^{80}$ Some sulphonylureas - but not others - have been shown to acutely increase the first-phase insulin response to glucose in hyperglycaemic clamp studies in individuals with T2D. ${ }^{81,82}$

In vitro studies of isolated human islets suggest that prolonged use of sulphonylureas may be toxic to beta-cells by inducing betacell apoptosis and loss of beta-cell mass. ${ }^{83}$ Clinical trials including UKPDS and ADOPT showed that sulphonylureas initially increase early-phase insulin secretion in response to OGTT, but then lead to a more rapid rate of deterioration in this measure of beta-cell function and overall glycaemic control than treatment with metformin, thiazolidinediones or insulin therapy (Figure 3). ${ }^{15,78,84}$ These studies highlight the concept of beta-cell 'rest' to preserve long-term islet function.

\section{Thiazolidinediones}

Thiazolidinediones (TZDs) are peroxisome proliferator-activated receptor-gamma (PPARY) agonists that regulate transcription of genes involved in lipid and glucose metabolism. The PPARY receptor is primarily expressed in adipose tissue, but also in pancreatic islet cells. 85 TZDs inhibit gluconeogenesis and enhance insulin sensitivity resulting in reduced fasting and postprandial glucose. ${ }^{86}$ TZDs also
Figure 3. Beta-cell function (determined by HOMA 2) over time, according to treatment group (rosiglitazone, metformin or glyburide monotherapy)

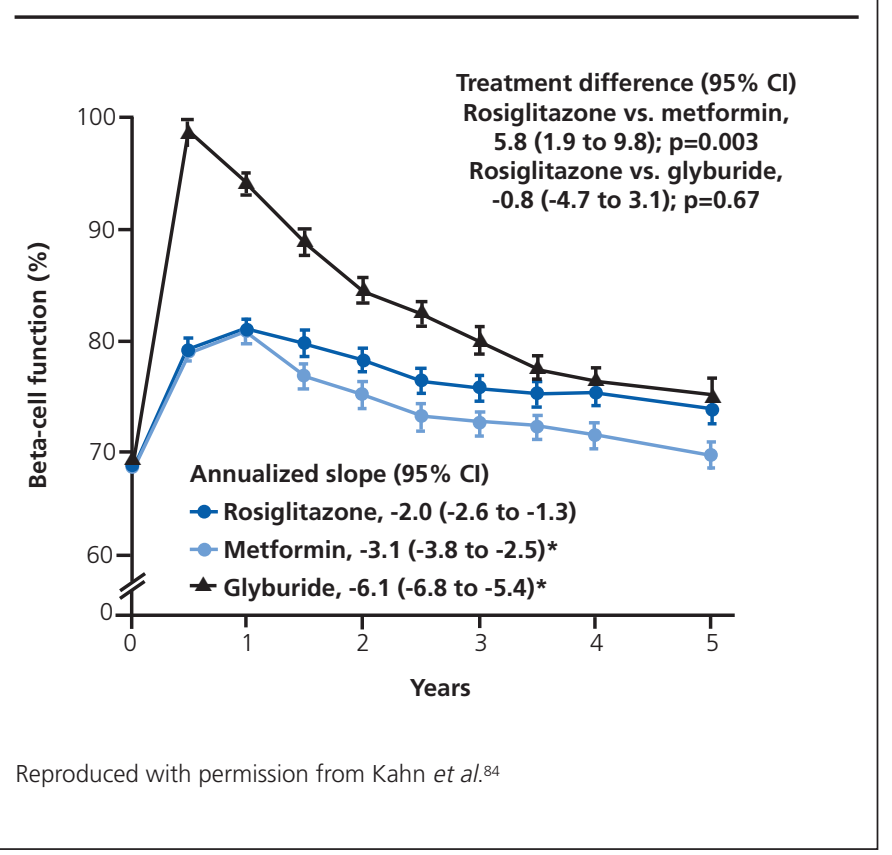

promote FFA uptake and storage in adipose tissue and reduce FFA release from adipocytes by enhancing the antilipolytic effect of insulin. 87

TZDs also have direct effects on beta-cells. Incubation of human islet cells with rosiglitazone prevented FFA-induced downregulation of insulin mRNA expression and restored islet insulin content and glucose-stimulated insulin release. This effect was associated with reduced intracellular levels of toxic lipid metabolites. ${ }^{88}$ TZDs also upregulate expression of genes involved in beta-cell glucose sensing, including GLUT2 and glucokinase, leading to increased beta-cell sensitivity to glucose and improved insulin secretory capacity following OGTT, even after correction of improved insulin resistance. 89,90

TZDs can restore first-phase insulin response and improve other markers of beta-cell function, an effect independent of the correction of glucotoxicity. ${ }^{91}$ Preservation of beta-cell function, in addition to insulin-sensitising effects, means that TZDs can slow progression of IGT to T2D by $50-75 \%$ in high-risk individuals. ${ }^{92-94}$ Patients protected from diabetes with TZD therapy had stable beta-cell function and stable insulin resistance for up to five years. ${ }^{95}$ The durability of effect of TZDs on beta-cell function in T2D is not clear; longer term studies of TZDs indicate that improvements in beta-cell function are sustained over two years in individuals with T2D uncontrolled with metformin or sulphonylurea monotherapy. ${ }^{96}$ In the ADOPT study, rosiglitazone was associated with the lowest incidence of treatment failure in recently diagnosed T2D compared with sulphonylureas and metformin. ${ }^{78}$

SGLT-2 inhibitors

Sodium glucose co-transporter 2 (SGLT-2) inhibitors block renal 
glucose reabsorption, leading to increased urinary glucose excretion and lower plasma glucose..$^{97}$ SGLT-2 inhibitors have been shown to exert protective effects on beta-cell function (increased GSIS) and mass in obese T2D db/db mice, ${ }^{98,99}$ an effect likely mediated by reduced beta-cell glucotoxicity. Improvements in beta-cell function have been reported with SGLT-2 treatment; canagliflozin use for six months improved HOMA-B. ${ }^{100}$ As SGLT-2 transporters are not present in beta-cells, the beneficial effects on function are unlikely to be direct beta-cell effects but secondary to improved glycaemic control, alleviating glucotoxicity.

Interestingly, SGLT-2 is expressed in pancreatic $\alpha$-cells and treatment with dapagliflozin increases glucagon secretion in human islets and in healthy mice, ${ }^{101}$ an effect which has been reported in clinical studies in individuals with T2D and leads to enhanced endogenous glucose production despite reduced fasting plasma glucose. ${ }^{102}$

\section{GLP-1 receptor agonists and DPP-4 inhibitors}

GLP-1 is an incretin hormone secreted in the distal ileum and colon in response to nutrient stimulation. Blunted GLP-1 secretion is seen in patients with T2D; however, GLP-1 receptors remain responsive to exogenous GLP-1. ${ }^{103}$ In addition to potentiating GSIS, GLP-1 slows gastric emptying, inhibits $\alpha$-cell glucagon secretion and reduces food intake. ${ }^{104} \mathrm{GLP}-1$ has a very short half-life, rapidly inactivated by dipeptidyl peptidase 4 (DPP-4). DPP-4 resistant GLP-1 agonists and DPP-4 inhibitors are licensed for the treatment of T2D.

GLP-1 promotes insulin mRNA expression within the beta-cell, leading to maintenance of intracellular insulin stores and improved beta-cell secretory capacity. ${ }^{105}$ GLP-1 also upregulates the biosynthesis of glucokinase and GLUT2, improving the capacity of betacells to sense and respond to glucose. ${ }^{106}$ Studies of animal models of T2D and studies of human islets suggest that GLP-1 agonists increase islet cell replication and inhibit apoptosis, resulting in increased beta-cell mass. 107,108

Treatment with either GLP-1 agonists or DPP-4 inhibitors, as monotherapy or in combination with other agents, can restore the first-phase insulin response. ${ }^{109-112}$ In the Liraglutide and the Preservation of Pancreatic $\beta$-Cell Function in Early Type 2 Diabetes (LIBRA) trial, following elimination of glucotoxicity with four weeks of IIT, treatment with liraglutide for 48 weeks led to further improvement in baseline adjusted insulin secretion to OGTT in patients with T2D. ${ }^{113}$

In animal studies, the protective effects of liraglutide on betacell function were more pronounced in the early stages of T2D than in the advanced stages. ${ }^{114}$ This reflects clinical studies in which the effect size of GLP-1 agonists on glycaemic control correlates with duration of T2D. ${ }^{115}$

Uncertainty remains regarding the optimal duration of treatment and durability of effect. Following cessation of GLP-1 treatment after one year (when improvements in beta-cell function were evident), the benefit was lost within weeks as beta-cell function returned to pre-treatment values. ${ }^{113}$ In contrast, individuals treated with exenatide for three years had sustained improvement in betacell function after a four-week washout compared with those receiving three years of insulin. ${ }^{116}$

\section{Early intensive insulin therapy (IIT)}

Reducing beta-cell demand with short-term IIT might allow chronically overstimulated beta-cells to replenish the secretable insulin pool and improve beta-cell viability, thereby inducing long-term glycaemic control.3,117 Treatment with either continuous subcutaneous insulin infusion (CSII) or multiple daily insulin injections (MDII) for two weeks achieved normoglycaemia in $95-97 \%$ of newly diagnosed patients with T2D. ${ }^{117}$ Normoglycaemia was maintained at one year in $44-51 \%$ of individuals (despite no additional antidiabetic therapy) compared with $27 \%$ initially treated with OHAs. ${ }^{117}$ The effect may persist for over two years. 3,118

The effect of short-term IIT early in T2D was to improve betacell function (first-phase insulin response, HOMA-B and proinsulin:insulin ratio).3,117,119 Restoration of first-phase insulin secretion predicted maintenance of euglycaemia at one year. ${ }^{3}$

What were the characteristics of the responders to IIT? These

Figure 4. Acute insulin response before and after different interventions and at 1 year

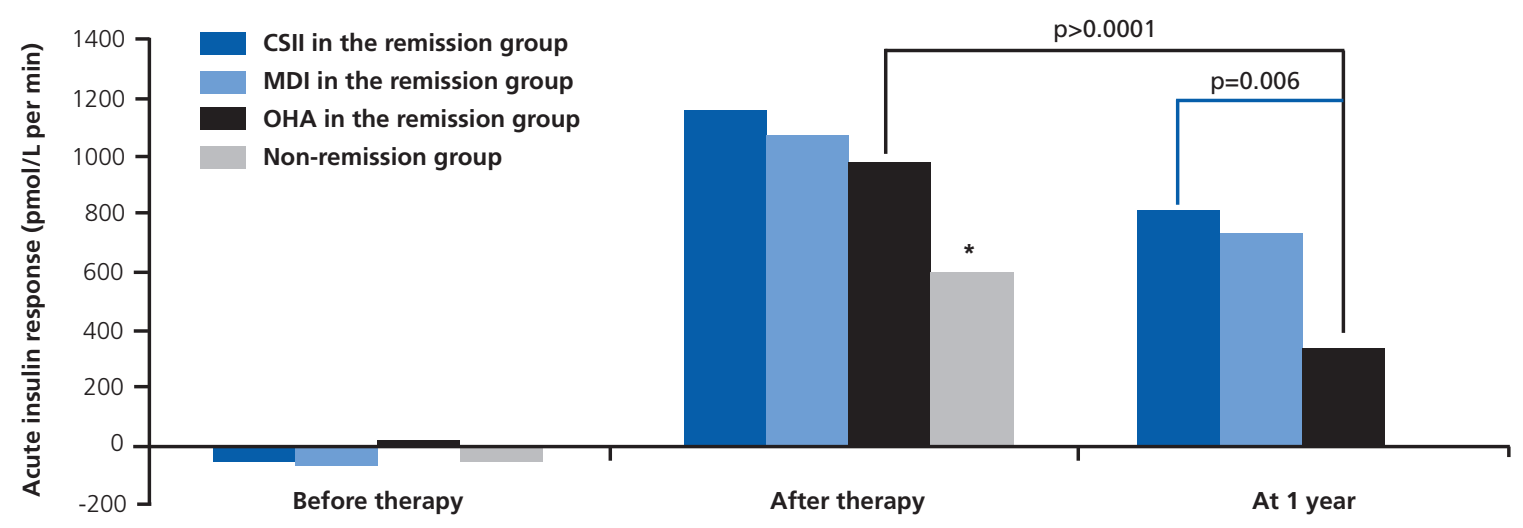

Reproduced with permission from Weng et al. ${ }^{117}$ 
individuals had a higher body mass index and lower FPG at baseline - possibly reflecting an intrinsic hyperinsulinaemic state. ${ }^{120}$ They also had better initial glycaemic control, shorter duration of diabetes, with fewer diabetic complications and earlier attainment of glycaemic targets following initiation of IIT. ${ }^{121,122}$ These factors suggest that individuals with relatively preserved beta-cell function at treatment onset respond better to IIT.

Amelioration of glucotoxicity is unlikely to be the sole cause for improved beta-cell function with IIT. Short-term IIT (MDII or CSII) and oral hypoglycaemic agents (gliclazide and/or metformin) can both achieve high rates of initial euglycaemia, but IIT leads to significantly higher rates of remission and preservation of first-phase insulin secretion after one year than oral hypoglycaemic agents (Figure 4). ${ }^{117}$ The anti-lipolytic, anti-inflammatory and anti-apoptotic properties of insulin may also contribute to this. ${ }^{123,124}$

Early introduction of short-term IIT has the potential to be a disease-modifying therapeutic option. The optimal approach for its implementation in clinical practice remains to be determined.

\section{Bariatric surgery}

Glycaemic control improves within several days following Rouxen-Y gastric bypass surgery (RYGB) in individuals with T2D. ${ }^{125} \mathrm{Im}$ provement in first-phase insulin secretion to an intravenous glucose tolerance test (IV GTT) occurs as early as one week after surgery, before significant changes in peripheral insulin sensitivity or weight have occurred. ${ }^{126}$ Dramatically reduced nutritional intake may lead to improved beta-cell function due to relief of glucotoxicity as a similar pattern of early improved hepatic insulin sensitivity is seen following energy restriction. ${ }^{4}$ Obese patients with T2D who underwent RYGB or $500 \mathrm{kcal} /$ day diet lost equivalent weight over three weeks and showed similar improvements in acute insulin secretion and beta-cell function in an IV GTT. ${ }^{65}$

Postprandial GLP-1 secretion is substantially and durably increased early after RYGB, before significant weight loss has occurred, due to increased delivery of nutrients to the distal small intestine. ${ }^{127}$ The importance of the incretin effect is unclear, with some studies showing that GLP-1 receptor blockade abolishes the RYGB-related improvement in beta-cell glucose sensitivity and insulin secretion ${ }^{127}$ while another study found only minimal impairment in glucose tolerance following GLP-1 blockade after RYGB. ${ }^{128}$

The durability of the effect of bariatric surgery on glycaemic control has been observed in the Swedish Obese Subjects Study; $72 \%$ of individuals with T2D achieved remission two years after surgery and 36\% had maintained T2D remission 10 years after surgery. ${ }^{129}$ Meta-analysis data report that $62 \%$ of patients with T2D remained free of diabetes for more than two years following surgery. ${ }^{130}$

Identifying the characteristics of patients likely to obtain the greatest benefit from surgery is critical. Several factors are associated with failure of glycaemic control: longer duration of T2D, more severe diabetes requiring insulin therapy before surgery, older age and inadequate postoperative weight loss. ${ }^{131}$ Many of these characteristics have been noted throughout this review as important predictors of success or failure of dietary or pharmacological treatment of T2D.

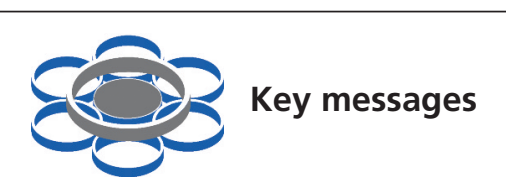

- Type 2 diabetes (T2D) is associated with progressive decline in beta-cell function with loss of first phase insulin response

- Loss of first phase insulin response is associated with increased cardiovascular risk

- Early intensive glycaemic control is associated with improved long-term morbidity and mortality

- Remission of T2D seen with very low calorie diet, intensive insulin therapy and bariatric surgery is associated with improved beta-cell function

- The greatest clinical benefit is observed when these interventions are delivered early in the course of T2D

\section{Conclusions}

With the potential for remission of diabetes seen with VLCD, early IIT and bariatric surgery, the focus of current treatment strategies needs to be revised. Interventions that preserve beta-cell function have improved durability on glycaemic control. It is not clear which intervention is most effective in achieving remission. However, the studies reviewed here suggest that several treatment options exist which, if delivered early enough in the course of T2D when betacell dysfunction is reversible, have the potential to preserve betacell function in the short and long term. Such interventions delivered after profound beta-cell failure has occurred are unlikely to be able to achieve remission of T2D. Aggressive treatment following diagnosis of T2D resulting in significant treatment-free periods is an attractive option. Comparative studies of different interventions in individuals with newly diagnosed T2D would be valuable to guide treatment recommendations.

Conflict of interest NM has received fees for serving as a speaker, a consultant or an advisory board member for Allergan, Bristol-Myers SquibbAstraZeneca, GlaxoSmithKline, Eli Lilly, Lifescan, MSD, Metronic, Novartis, Novo Nordisk, Pfizer, Sankio, Sanofi, Roche, Servier, Takeda.

MW has received speaker and consultancy fees from AstraZeneca and Boehringer Ingelheim and research funding from Sanofi and Eli Lilly.

Funding $\mathrm{CB}$ is funded by NIHR as an Academic Clinical Fellow in Diabetes and Endocrinology.

\section{References}

1. Turner RC, Cull CA, Frighi V, Holman RR. Glycemic control with diet, sulfonylurea, metformin, or insulin in patients with type 2 diabetes mellitus: progressive requirement for multiple therapies (UKPDS 49). UK Prospective Diabetes Study (UKPDS) Group. JAMA 1999;281:2005-12. https://doi.org/10.1001/jama.281.21.2005

2. Polyzogopoulou EV, Kalfarentzos F, Vagenakis AG, Alexandrides TK Restoration of euglycemia and normal acute insulin response to glucose in obese subjects with type 2 diabetes following bariatric surgery. Diabetes 2003:52:1098-103. https://doi.org/10.2337/diabetes.52.5.1098

3. Li Y, Xu W, Liao Z, et al. Induction of long-term glycemic control in newly diagnosed type 2 diabetic patients is associated with improvement of beta-cell function. Diabetes Care 2004;27:2597-602. 
https://doi.org/10.2337/diacare.27.11.2597

4. Lim EL, Hollingsworth KG, Aribisala BS, Chen MJ, Mathers JC, Taylor R. Reversal of type 2 diabetes: normalisation of beta cell function in association with decreased pancreas and liver triacylglycerol. Diabetologia 2011;54:2506-14. http://dx.doi.org/10.1007/s00125-011-2204-7

5. National Institute for Health and Care Excellence (NICE). NICE guideline [NG 28]. Type 2 diabetes in adults: management. December 2015

6. National Diabetes Audit 2013-2014 and 2014-2015. Report 1: Care Processes and Treatment Targets. Health and Social Care Information Centre. 28 January 2016

7. Holman RR, Paul SK, Bethel MA, Matthews DR, Neil HA. 10-year follow-up of intensive glucose control in type 2 diabetes. N Engl J Med 2008;359:1577-89. http://dx.doi.org/10.1056/NEJMoa0806470

8. Defronzo RA. Banting Lecture. From the triumvirate to the ominous octet: a new paradigm for the treatment of type 2 diabetes mellitus. Diabetes 2009;58:773-95. http://dx.doi.org/10.2337/db09-9028

9. Ferrannini E, Natali A, Bell P, Cavallo-Perin P, Lalic N, Mingrone G. Insulin resistance and hypersecretion in obesity. European Group for the Study of Insulin Resistance (EGIR). J Clin Invest 1997:100:1166-73. https://doi.org/10.1172/JCI119628

10. Weyer C, Bogardus C, Mott DM, Pratley RE. The natural history of insulin secretory dysfunction and insulin resistance in the pathogenesis of type 2 diabetes mellitus. J Clin Invest 1999;104:787-94. https://doi.org/10.1172/JCI7231

11. Taylor R. Pathogenesis of type 2 diabetes: tracing the reverse route from cure to cause. Diabetologia 2008;51:1781-9. http://dx.doi.org/10.1007/s00125-008-1116-7

12. Tabak AG, Jokela M, Akbaraly TN, Brunner EJ, Kivimaki M, Witte DR. Trajectories of glycaemia, insulin sensitivity, and insulin secretion before diagnosis of type 2 diabetes: an analysis from the Whitehall II study. Lancet 2009;373:2215-21. http://dx.doi.org/10.1016/S0140-6736(09)60619-X

13. Weir GC, Bonner-Weir S. Five stages of evolving beta-cell dysfunction during progression to diabetes. Diabetes 2004;53(Suppl 3):S16-21.

14. Brown RJ, Rother KI. Effects of beta-cell rest on beta-cell function: a review of clinical and preclinical data. Pediatr Diabetes 2008:9/3 Pt 2):14-22. http://dx.doi.org/10.1111/j.1399-5448.2007.00272.x

15. UK Prospective Diabetes Study 16: Overview of 6 years' therapy of type II diabetes: a progressive disease. Diabetes 1995;44:1249-58. https://doi.org/10.2337/diab.44.11.1249

16. Fonseca VA. Defining and characterizing the progression of type 2 diabetes. Diabetes Care 2009;32(Suppl 2):S151-6. http://dx.doi.org/ 10.2337/dc09-S301

17. Talchai $C$, Xuan $S$, Lin HV, Sussel L, Accili D. Pancreatic $\beta$-cell dedifferentiation as mechanism of diabetic $\beta$-cell failure. Cell 2012;150:122334. http://dx.doi.org/10.1016/j.cell.2012.07.029

18. Robertson RP, Zhang HJ, Pyzdrowski KL, Walseth TF. Preservation of insulin mRNA levels and insulin secretion in HIT cells by avoidance of chronic exposure to high glucose concentrations. J Clin Invest 1992;90:320-5. https://doi.org/10.1172/JCI115865

19. Robertson RP, Harmon J, Tran PO, Tanaka Y, Takahashi H. Glucose toxicity in $\beta$-cells: type 2 diabetes, good radicals gone bad, and the glutathione connection. Diabetes 2003;52:581-7. https://doi.org/10.2337/diabetes.52.3.581

20. Gleason CE, Gonzalez M, Harmon JS, Robertson RP. Determinants of glucose toxicity and its reversibility in the pancreatic islet beta-cell line, HIT-T15. Am J Physiol Endocrinol Metab 2000;279:E997-1002.

21. Zhou YP, Grill VE. Long-term exposure of rat pancreatic islets to fatty acids inhibits glucose-induced insulin secretion and biosynthesis through a glucose fatty acid cycle. J Clin Invest 1994;93:870-6. https://doi.org/10.1172/JCl117042

22. Cnop M, Hannaert JC, Hoorens A, Eizirik DL, Pipeleers DG. Inverse relationship between cytotoxicity of free fatty acids in pancreatic islet cells and cellular triglyceride accumulation. Diabetes 2001;50:1771-7. https://doi.org/10.2337/diabetes.50.8.1771

23. Poitout V, Amyot J, Semache M, Zarrouki B, Hagman D, Fontes G. Glucolipotoxicity of the pancreatic beta cell. Biochim Biophys Acta 2010;1801:289-98. http://dx.doi.org/10.1016/j.bbalip.2009.08.006

24. Hasnain SZ, Prins JB, McGuckin MA. Oxidative and endoplasmic reticulum stress in $\beta$-cell dysfunction in diabetes. J Mol Endocrinol
2016;56:R33-R54. http://dx.doi.org/10.1530/JME-15-0232

25. Tiedge M, Lortz S, Drinkgern J, Lenzen S. Relation between antioxidant enzyme gene expression and antioxidative defense status of insulin-producing cells. Diabetes 1997;46:1733-42. https://doi.org/10.2337/diab.46.11.1733

26. Robertson RP. Oxidative stress and impaired insulin secretion in type 2 diabetes. Curr Opin Pharmacol 2006;6:615-19. http://dx.doi.org/10.1016/j.coph.2006.09.002

27. Del Guerra S, Lupi R, Marselli L, et al. Functional and molecular defects of pancreatic islets in human type 2 diabetes. Diabetes 2005;54:72735. https://doi.org/10.2337/diabetes.54.3.727

28. Paolisso G, Giugliano D, Pizza G, et al. Glutathione infusion potentiates glucose-induced insulin secretion in aged patients with impaired glucose tolerance. Diabetes Care 1992;15:1-7. https://doi.org/10.2337/diacare.15.1.1

29. Masha A, Brocato L, Dinatale S, Mascia C, Biasi F, Martina V. N-acetylcysteine is able to reduce the oxidation status and the endothelial activation after a high-glucose content meal in patients with type 2 diabetes mellitus. J Endocrinol Invest 2009:32:352-6. http://dx.doi.org/10.1007/BF03345726

30. Eizirik DL, Cardozo AK, Cnop M. The role for endoplasmic reticulum stress in diabetes mellitus. Endocrinol Rev 2008;29:42-61. http://dx.doi.org/10.1210/er.2007-0015

31. Laybutt DR, Preston AM, Akerfeldt MC, et al. Endoplasmic reticulum stress contributes to beta cell apoptosis in type 2 diabetes. Diabetologia 2007;50:752-63. http://dx.doi.org/10.1007/s00125-006-0590-z

32. Marchetti P, Bugliani M, Lupi R, et al. The endoplasmic reticulum in pancreatic beta cells of type 2 diabetes patients. Diabetologia 2007:50:2486-94. http://dx.doi.org/10.1007/s00125-007-0816-8

33. Richardson SJ, Willcox A, Bone AJ, Foulis AK, Morgan NG. Islet-associated macrophages in type 2 diabetes. Diabetologia 2009;52:1686-8. http://dx.doi.org/10.1007/s00125-009-1410-z

34. Boni-Schnetzler M, Thorne J, Parnaud G, et al. Increased interleukin (IL)1 beta messenger ribonucleic acid expression in beta-cells of individuals with type 2 diabetes and regulation of IL-1 beta in human islets by glucose and autostimulation. J Clin Endocrinol Metab 2008:93:4065-74. http://dx.doi.org/10.1210/jc.2008-0396

35. Eldor R, Yeffet A, Baum K, et al. Conditional and specific NF-kappaB blockade protects pancreatic beta cells from diabetogenic agents. Proc Natl Acad Sci USA 2006;103:5072-7.

http://dx.doi.org/10.1073/pnas.0508166103

36. Maedler K, Sergeev P, Ris F, et al. Glucose-induced beta cell production of IL-1 beta contributes to glucotoxicity in human pancreatic islets. J Clin Invest 2002;110:851-60. http://dx. doi.org/10.1172/JCI15318

37. Larsen CM, Faulenbach $M$, Vaag A, et al. Interleukin-1-receptor antagonist in type 2 diabetes mellitus. N Engl J Med 2007:356:1517-26. http://dx.doi.org/10.1097/PCC.0b013e318198b139

38. Jurgens CA, Toukatly MN, Fligner $\mathrm{CL}$, et al. Beta-cell loss and beta-cell apoptosis in human type 2 diabetes are related to islet amyloid deposition. Am J Pathol 2011:178:2632-40. http://dx.doi.org/10.1016/j.ajpath.2011.02.036

39. Montane J, Klimek-Abercrombie A, Potter KJ, Westwell-Roper C, Bruce Verchere C. Metabolic stress, IAPP and islet amyloid. Diabetes Obes Metab 2012:14(Suppl 3):68-77. http://dx.doi.org/10.1111/j.1463-1326.2012.01657.x

40. Rorsman P, Eliasson L, Renström E, Gromada J, Barg S, Göpel S. The cell physiology of biphasic insulin secretion. Physiology 2000;15:72-7.

41. Ratzmann KP, Schulz B, Witt S, Heinke P, Ziegler M. Changes of early insulin responses to glucose in obese subjects with normal and impaired carbohydrate tolerance. Endokrinologie 1981;78:89-98.

42. Ryan EA, Imes $\mathrm{S}$, Liu D, et al. Defects in insulin secretion and action in women with a history of gestational diabetes. Diabetes 1995;44:50612. https://doi.org/10.2337/diab.44.5.506

43. Eriksson J, Franssila-Kallunki A, Ekstrand A, et al. Early metabolic defects in persons at increased risk for non-insulin-dependent diabetes mellitus. N Engl J Med 1989;321:337-43. http://dx.doi.org/10.1056/NEJM198908103210601

44. Coutinho M, Gerstein HC, Wang Y, Yusuf S. The relationship between glucose and incident cardiovascular events. A metaregression analysis of published data from 20 studies of 95,783 individuals followed for 
12.4 years. Diabetes Care 1999;22:233-40. https://doi.org/10.2337/diacare.22.2.233

45. Bruttomesso D, Pianta A, Mari A, et al. Restoration of early rise in plasma insulin levels improves the glucose tolerance of type 2 diabetic patients. Diabetes 1999;48:99-105. https://doi.org/10.2337/diabetes.48.1.99

46. Leahy JL, Bonner-Weir S, Weir GC. Beta-cell dysfunction induced by chronic hyperglycemia. Current ideas on mechanism of impaired glucose-induced insulin secretion. Diabetes Care 1992:15:442-55. https://doi.org/10.2337/diacare.15.3.442

47. Temple RC, Clark PM, Nagi DK, Schneider AE, Yudkin JS, Hales CN. Radioimmunoassay may overestimate insulin in non-insulin-dependent diabetics. Clin Endocrinol 1990;32:689-93. https://doi.org/10.1111/j.1365-2265.1990.tb00915.x

48. Butler AE, Janson J, Bonner-Weir S, Ritzel R, Rizza RA, Butler PC. Betacell deficit and increased beta-cell apoptosis in humans with type 2 diabetes. Diabetes 2003;52:102-10. https://doi.org/10.2337/diabetes. 52.1.102

49. Sourij $\mathrm{H}$, Saely $\mathrm{CH}$, Schmid F, et al. Post-challenge hyperglycaemia is strongly associated with future macrovascular events and total mortality in angiographied coronary patients. Eur Heart J 2010;31:1583-90. http://dx.doi.org/10.1093/eurheartj/ehq099

50. Raz I, Wilson PW, Strojek K, et al. Effects of prandial versus fasting glycemia on cardiovascular outcomes in type 2 diabetes: the HEART2D trial. Diabetes Care 2009;32:381-6. http://dx.doi.org/10.2337/dc08-1671

51. Raz I, Ceriello A, Wilson PW, et al. Post hoc subgroup analysis of the HEART2D trial demonstrates lower cardiovascular risk in older patients targeting postprandial versus fasting/premeal glycemia. Diabetes Care 2011;34:1511-3. http://dx. doi.org/10.2337/dc10-2375

52. NAVIGATOR Study Group. Effect of nateglinide on the incidence of diabetes and cardiovascular events. N Engl J Med 2010;362:1463-76. http://dx.doi.org/10.1056/NEJMoa1001122

53. Chiasson JL, Josse RG, Gomis R, Hanefeld M, Karasik A, Laakso M. Acarbose treatment and the risk of cardiovascular disease and hypertension in patients with impaired glucose tolerance: the STOP-NIDDM trial. JAMA 2003;290:486-94. http://dx.doi.org/10.1001/jama.290.4.486

54. UK Prospective Diabetes Study (UKPDS) Group. Intensive blood-glucose control with sulphonylureas or insulin compared with conventional treatment and risk of complications in patients with type 2 diabetes (UKPDS 33). Lancet 1998:352:837-53.

55. Gerstein HC, Bosch J, Dagenais GR, et al. Basal insulin and cardiovascular and other outcomes in dysglycemia. N Engl J Med 2012;367:31928. http://dx.doi.org/10.1056/NEJMoa1203858

56. Gæde $\mathrm{P}$, Lund-Andersen $\mathrm{H}$, Parving $\mathrm{H}-\mathrm{H}$, Pedersen $\mathrm{O}$. Effect of a multifactorial intervention on mortality in type 2 diabetes. $N$ Engl J Med 2008:358:580-91. http://dx.doi.org/10.1056/NEJMoa0706245

57. Duckworth W, Abraira C, Moritz T, et al. Glucose control and vascular complications in veterans with type 2 diabetes. N Engl J Med 2009; 360:129-39. http://dx.doi.org/10.1056/NEJMoa0808431

58. Action to Control Cardiovascular Risk in Diabetes Study Group. Effects of intensive glucose lowering in type 2 diabetes. N Engl J Med 2008; 358:2545-59. http://dx.doi.org/10.1056/NEJMoa0802743

59. ADVANCE Collaborative Group. Intensive blood glucose control and vascular outcomes in patients with type 2 diabetes. N Engl J Med 2008;358:2560-72. http://dx.doi.org/10.1056/NEJMoa0802987

60. Gerstein HC, Miller ME, Ismail-Beigi F, et al. Effects of intensive glycaemic control on ischaemic heart disease: analysis of data from the randomised, controlled ACCORD trial. Lancet 2014;384:1936-41. http://dx.doi.org/10.1016/S0140-6736(14)60611-5

61. Action to Control Cardiovascular Risk in Diabetes Study Group. Effects of intensive glucose lowering in type 2 diabetes. N Engl J Med 2008; 358:2545-59. http://dx.doi.org/10.1056/NEJMoa0802743

62. ACCORD Study Group. Nine-year effects of 3.7 years of intensive glycemic control on cardiovascular outcomes. Diabetes Care 2016;39:701-08. http://dx.doi.org/10.2337/dc15-2283

63. Zoungas S, Chalmers J, Neal B, et al. Follow-up of blood-pressure lowering and glucose control in type 2 diabetes. N Engl J Med 2014;371:1392-406. http://dx. doi.org/10.1056/NEJMoa1407963

64. Henry RR, Scheaffer L, Olefsky JM. Glycemic effects of intensive caloric restriction and isocaloric refeeding in noninsulin-dependent diabetes mellitus. J Clin Endocrinol Metab 1985;61:917-25

https://doi.org/10.1210/jcem-61-5-917

65. Jackness C, Karmally W, Febres G, et al. Very low-calorie diet mimics the early beneficial effect of Roux-en-Y gastric bypass on insulin sensitivity and beta-cell function in type 2 diabetic patients. Diabetes 2013; 62:3027-32. http://dx.doi.org/10.2337/db12-1762

66. Malandrucco I, Pasqualetti P, Giordani I, et al. Very-low-calorie diet: a quick therapeutic tool to improve beta cell function in morbidly obese patients with type 2 diabetes. Am J Clin Nutr 2012;95:609-13. http://dx.doi.org/10.3945/ajcn.111.023697

67. Jazet IM, de Craen AJ, van Schie EM, Meinders AE. Sustained beneficial metabolic effects 18 months after a 30-day very low calorie diet in severely obese, insulin-treated patients with type 2 diabetes. Diabetes Res Clin Pract 2007;77:70-6. http://dx.doi.org/10.1016/j.diabres.2006.10.019

68. Wing RR, Marcus MD, Salata R, Epstein LH, Miaskiewicz S, Blair EH. Effects of a very-low-calorie diet on long-term glycemic control in obese type 2 diabetic subjects. Arch Intern Med 1991;151:1334-40. https://doi.org/10.1001/archinte.1991.00400070100012

69. Dhindsa P, Scott AR, Donnelly R. Metabolic and cardiovascular effects of very-low-calorie diet therapy in obese patients with type 2 diabetes in secondary failure: outcomes after 1 year. Diabet Med 2003;20:31924. https://doi.org/10.1046/j.1464-5491.2003.00937.x

70. Steven S, Taylor R. Restoring normoglycaemia by use of a very low calorie diet in long- and short-duration type 2 diabetes. Diabet Med 2015;32:1149-55. http://dx.doi.org/10.1111/dme.12722

71. Steven $\mathrm{S}$, Hollingsworth KG, Al-Mrabeh $A$, et al. Very-low-calorie diet and 6 months of weight stability in type 2 diabetes: pathophysiologic changes in responders and nonresponders. Diabetes Care 2016;39:80815. http://dx.doi.org/10.2337/dc15-1942

72. Thomas DE, Elliott EJ, Naughton GA. Exercise for type 2 diabetes mellitus. Cochrane Database Syst Rev 2006(3):Cd002968.

73. Michishita R, Shono N, Kasahara T, Tsuruta T. Effects of low intensity exercise therapy on early phase insulin secretion in overweight subjects with impaired glucose tolerance and type 2 diabetes mellitus. Diabetes Res Clin Pract 2008:82:291-7.

http://dx.doi.org/10.1016/j.diabres.2008.08.013

74. Solomon TPJ, Haus JM, Kelly KR, Rocco M, Kashyap SR, Kirwan JP. Improved pancreatic $\beta$-cell function in type 2 diabetic patients after lifestyle-induced weight loss is related to glucose-dependent insulinotropic polypeptide. Diabetes Care 2010;33:1561-6. http://dx.doi.org/10.2337/dc09-2021

75. Dela F, von Linstow ME, Mikines KJ, Galbo H. Physical training may enhance $\beta$-cell function in type 2 diabetes. Am J Physiol Endocrinol Metab 2004;287:E1024-31. http://dx.doi.org/10.1152/ajpendo.00056.2004

76. Lupi $R$, Del Guerra S, Fierabracci $V$, et al. Lipotoxicity in human pancreatic islets and the protective effect of metformin. Diabetes 2002;51(Suppl 1):S134-7.

77. Patane G, Piro S, Rabuazzo AM, Anello M, Vigneri R, Purrello F. Metformin restores insulin secretion altered by chronic exposure to free fatty acids or high glucose: a direct metformin effect on pancreatic beta-cells. Diabetes 2000:49:735-40. https://doi.org/10.2337/diabetes.49.5.735

78. Kahn SE, Lachin JM, Zinman B, et al. Effects of rosiglitazone, glyburide, and metformin on beta-cell function and insulin sensitivity in ADOPT. Diabetes 2011;60:1552-60. http://dx.doi.org/10.2337/db10-1392

79. Sun W, Zeng C, Liao L, Chen J, Wang Y. Comparison of acarbose and metformin therapy in newly diagnosed type 2 diabetic patients with overweight and/or obese. Curr Med Res Opin 2016:32:1389-96. http://dx.doi.org/10.1080/03007995.2016.1176013

80. Lang $\vee$, Youssef N, Light PE. The molecular genetics of sulfonylurea receptors in the pathogenesis and treatment of insulin secretory disorders and type 2 diabetes. Curr Diabetes Rep 2011;11:543-51. http://dx.doi.org/10.1007/s11892-011-0233-8

81. Korytkowski M, Thomas A, Reid L, Tedesco MB, Gooding WE, Gerich J. Glimepiride improves both first and second phases of insulin secretion in type 2 diabetes. Diabetes Care 2002;25:1607-11. https://doi.org/10.2337/diacare.25.9.1607

82. Ligtenberg JJ, Reitsma WD, van Haeften TW. Gliclazide mainly affects insulin secretion in second phase of type 2 diabetes mellitus. Horm Metab Res 2001;33:361-4. http://dx.doi.org/10.1055/s-2001-15411 
83. Maedler K, Carr RD, Bosco D, Zuellig RA, Berney T, Donath MY. Sulfonylurea induced beta-cell apoptosis in cultured human islets. J Clin Endocrinol Metab 2005;90:501-06. http://dx.doi.org/10.1210/jc.2004-0699

84. Kahn SE, Haffner SM, Heise MA, et al. Glycemic durability of rosiglitazone, metformin, or glyburide monotherapy. $N$ Engl J Med 2006;355:2427-43. https://doi.org/10.1056/NEJMoa066224

85. Dubois M, Pattou F, Kerr-Conte J, et al. Expression of peroxisome proliferator-activated receptor $y$ (PPARY) in normal human pancreatic islet cells. Diabetologia 2000;43:1165-9. https://doi.org/10.1007/s001250051508

86. Gastaldelli A, Miyazaki Y, Pettiti M, et al. The effect of rosiglitazone on the liver: decreased gluconeogenesis in patients with type 2 diabetes. J Clin Endocrinol Metab 2006;91:806-12. http://dx.doi.org/10.1210/jc.2005-1159

87. Yki-Jarvinen H. Thiazolidinediones. N Engl J Med 2004;351:1106-18. http://dx.doi.org/10.1056/NEJMra041001

88. Lupi R, Del Guerra S, Marselli L, et al. Rosiglitazone prevents the impairment of human islet function induced by fatty acids: evidence for a role of PPARgamma2 in the modulation of insulin secretion. Am J Physiol Endocrinol Metab 2004:286:E560-7.

89. Kim HI, Cha JY, Kim SY, et al. Peroxisomal proliferator-activated receptor-gamma upregulates glucokinase gene expression in beta-cells. Diabetes 2002;51:676-85. https://doi.org/10.2337/diabetes.51.3.676

90. Gastaldelli A, Ferrannini E, Miyazaki Y, Matsuda M, Mari A, DeFronzo RA. Thiazolidinediones improve beta-cell function in type 2 diabetic patients. Am J Physiol Endocrinol Metab 2007:292:E871-83.

91. Ovalle F, Bell DS. Effect of rosiglitazone versus insulin on the pancreatic beta-cell function of subjects with type 2 diabetes. Diabetes Care 2004;27:2585-9. https://doi.org/10.2337/diacare.27.11.2585

92. Buchanan TA, Xiang AH, Peters RK, et al. Preservation of pancreatic $\beta$ cell function and prevention of type 2 diabetes by pharmacological treatment of insulin resistance in high-risk hispanic women. Diabetes 2002:51:2796-803. https://doi.org/10.2337/diabetes.51.9.2796

93. Gerstein HC, Yusuf S, Bosch J, et al. Effect of rosiglitazone on the frequency of diabetes in patients with impaired glucose tolerance or impaired fasting glucose: a randomised controlled trial. Lancet 2006; 368:1096-105. http://dx.doi.org/10.1016/S0140-6736(06)69420-8

94. DeFronzo RA, Tripathy D, Schwenke DC, et al. Pioglitazone for diabetes prevention in impaired glucose tolerance. N Eng/ J Med 2011;364:110415. http://dx.doi.org/10.1056/NEJMoa1010949

95. Xiang AH, Peters RK, Kjos SL, et al. Effect of pioglitazone on pancreatic beta-cell function and diabetes risk in Hispanic women with prior gestational diabetes. Diabetes 2006;55:517-22. https://doi.org/10.2337/diabetes.55.02.06.db05-1066

96. Charbonnel B, Schernthaner G, Brunetti $\mathrm{P}$, et al. Long-term efficacy and tolerability of add-on pioglitazone therapy to failing monotherapy compared with addition of gliclazide or metformin in patients with type 2 diabetes. Diabetologia 2005;48:1093-104. http://dx.doi.org/10.1007/s00125-005-1751-1

97. Chao EC, Henry RR. SGLT2 inhibition - a novel strategy for diabetes treatment. Nat Rev Drug Discov 2010;9:551-9. http://dx.doi.org/10.1038/nrd3180

98. Shimo N, Matsuoka TA, Miyatsuka T, et al. Short-term selective alleviation of glucotoxicity and lipotoxicity ameliorates the suppressed expression of key beta-cell factors under diabetic conditions. Biochem Biophys Res Commun 2015;467:948-54. http://dx.doi.org/10.1016/j.bbrc.2015.10.038

99. Okauchi S, Shimoda M, Obata A, et al. Protective effects of SGLT2 inhibitor luseogliflozin on pancreatic beta-cells in obese type 2 diabetic $\mathrm{db} / \mathrm{db}$ mice. Biochem Biophys Res Commun 2016:470:772-82. http://dx.doi.org/10.1016/j.bbrc.2015.10.109

100. Rosenstock J, Aggarwal N, Polidori D, et al. Dose-ranging effects of canagliflozin, a sodium-glucose cotransporter 2 inhibitor, as add-on to metformin in subjects with type 2 diabetes. Diabetes Care 2012;35:1232-8. http://dx.doi.org/10.2337/dc11-1926

101.Bonner C, Kerr-Conte J, Gmyr V, et al. Inhibition of the glucose transporter SGLT2 with dapagliflozin in pancreatic alpha cells triggers glucagon secretion. Nat Med 2015;21:512-17. http://dx.doi.org/10.1038/nm.3828
102. Merovci A, Solis-Herrera C, Daniele G, et al. Dapagliflozin improves muscle insulin sensitivity but enhances endogenous glucose production. J Clin Invest 2014;124:509-14. http://dx.doi.org/10.1172/JCI70704

103. Nauck MA, Heimesaat MM, Orskov C, Holst JJ, Ebert R, Creutzfeldt W. Preserved incretin activity of glucagon-like peptide 1 [7-36 amide] but not of synthetic human gastric inhibitory polypeptide in patients with type-2 diabetes mellitus. J Clin Invest 1993;91:301-07. https://doi.org/10.1172/JCI116186

104.Drucker DJ, Nauck MA. The incretin system: glucagon-like peptide-1 receptor agonists and dipeptidyl peptidase-4 inhibitors in type 2 diabetes. Lancet 2006:368:1696-705

http://dx.doi.org/10.1016/S0140-6736(06)69705-5

105.Drucker DJ, Philippe J, Mojsov S, Chick WL, Habener JF. Glucagon-like peptide I stimulates insulin gene expression and increases cyclic AMP levels in a rat islet cell line. Proc Natl Acad Sci USA 1987:84:3434-8. https://doi.org/10.1073/pnas.84.10.3434

106. Holz GG 4th, Kiihtreiber WM, Habener JF. Pancreatic beta-cells are rendered glucose-competent by the insulinotropic hormone glucagon-like peptide-1(7-37). Nature 1993;361:362-5. https://doi.org/10.1038/361362a0

107. Xu G, Stoffers DA, Habener JF, Bonner-Weir S. Exendin-4 stimulates both beta-cell replication and neogenesis, resulting in increased beta-cell mass and improved glucose tolerance in diabetic rats. Diabetes 1999;48:2270-6. https://doi.org/10.2337/diabetes.48.12.2270

108.Farilla L, Bulotta A, Hirshberg B, et al. Glucagon-like peptide 1 inhibits cell apoptosis and improves glucose responsiveness of freshly isolated human islets. Endocrinology 2003;144:5149-58. http://dx.doi.org/10.1210/en.2003-0323

109. Vilsboll T, Brock B, Perrild H, et al. Liraglutide, a once-daily human GLP1 analogue, improves pancreatic B-cell function and arginine-stimulated insulin secretion during hyperglycaemia in patients with type 2 diabetes mellitus. Diabet Med 2008;25:152-6. http://dx.doi.org/10.1111/j.1464-5491.2007.02333.x

110.Derosa G, Franzetti IG, Querci F, et al. Exenatide plus metformin compared with metformin alone on beta-cell function in patients with type 2 diabetes. Diabet Med 2012;29:1515-23. http://dx.doi.org/10.1111/j.1464-5491.2012.03699.x

111.Derosa G, Carbone A, D'Angelo A, et al. A randomized, double-blind, placebo-controlled trial evaluating sitagliptin action on insulin resistance parameters and beta-cell function. Expert Opin Pharmacother 2012;13:2433-42. http://dx.doi.org/10.1517/14656566.2012.730519

112.Ohkura T, Fujioka Y, Sumi K, et al. Sitagliptin improves the impaired acute insulin response during a meal tolerance test in Japanese patients with type 2 diabetes mellitus: a small-scale real-world study. Diabetes Ther 2014;5:285-97. http://dx.doi.org/10.1007/s13300-014-0071-1

113. Retnakaran R, Kramer CK, Choi H, Swaminathan B, Zinman B. Liraglutide and the preservation of pancreatic beta-cell function in early type 2 diabetes: the LIBRA trial. Diabetes Care 2014;37:3270-8. http://dx.doi.org/10.2337/dc14-0893

114. Kimura T, Kaneto $\mathrm{H}$, Shimoda $\mathrm{M}$, et al. Protective effects of pioglitazone and/or liraglutide on pancreatic beta-cells in $\mathrm{db} / \mathrm{db}$ mice: comparison of their effects between in an early and advanced stage of diabetes. Mol Cell Endocrinol 2015;400:78-89. http://dx.doi.org/10.1016/j.mce.2014.11.018

115. Ross SA, Ballantine J. Early use of glucagon-like peptide-1 receptor agonists (GLP-1 RAs) in type 2 diabetes. Curr Med Res Opin 2013:29:1617-26. http://dx.doi.org/10.1185/03007995.2013.837817

116. Bunck MC, Cornér $A$, Eliasson $B$, et al. Effects of exenatide on measures of $\beta$-cell function after 3 years in metformin-treated patients with type 2 diabetes. Diabetes Care 2011:34:2041-7. http://dx.doi.org/10.2337/dc11-0291

117. Weng J, Li Y, Xu W, et al. Effect of intensive insulin therapy on beta-cell function and glycaemic control in patients with newly diagnosed type 2 diabetes: a multicentre randomised parallel-group trial. Lancet 2008:371:1753-60. http://dx. doi.org/10.1016/S0140-6736(08)60762-X

118.Xu W, Li YB, Deng WP, Hao YT, Weng JP. Remission of hyperglycemia following intensive insulin therapy in newly diagnosed type 2 diabetic patients: a long-term follow-up study. Chinese Med J 2009;122:2554-9.

119. Chen HS, Wu TE, Jap TS, Hsiao LC, Lee SH, Lin HD. Beneficial effects of insulin on glycemic control and beta-cell function in newly diagnosed 
type 2 diabetes with severe hyperglycemia after short-term intensive insulin therapy. Diabetes Care 2008;31:1927-32. http://dx.doi.org/10.2337/dc08-0075

120. Kramer CK, Zinman B, Retnakaran R. Short-term intensive insulin therapy in type 2 diabetes mellitus: a systematic review and meta-analysis. Lancet Diabetes Endocrinol 2013:1:28-34 http://dx.doi.org/10.1016/S2213-8587(13)70006-8

121. Retnakaran R, Yakubovich N, Qi Y, Opsteen C, Zinman B. The response to short-term intensive insulin therapy in type 2 diabetes. Diabetes Obes Metab 2010;12:65-71. http://dx.doi.org/10.1111/j.1463-1326.2009.01129.x

122.Park S, Choi SB. Induction of long-term normoglycemia without medication in Korean type 2 diabetes patients after continuous subcutaneous insulin infusion therapy. Diabetes Metab Res Rev 2003; 19:124-30. http://dx.doi.org/10.1002/dmrr.343

123. Retnakaran R, Zinman B. Short-term intensified insulin treatment in type 2 diabetes: long-term effects on beta-cell function. Diabetes Obes Metab 2012;14(Suppl 3):161-6. http://dx.doi.org/10.1111/j.1463-1326.2012.01658.x

124.Chen H, Ren A, Hu S, Mo W, Xin X, Jia W. The significance of tumor necrosis factor- $\alpha$ in newly diagnosed type 2 diabetic patients by transient intensive insulin treatment. Diabetes Res Clin Pract 2007;75:32732. http://dx.doi.org/10.1016/j.diabres.2006.07.001

125.Bojsen-Moller KN, Dirksen C, Jorgensen NB, et al. Early enhancements of hepatic and later of peripheral insulin sensitivity combined with increased postprandial insulin secretion contribute to improved glycemic control after Roux-en-Y gastric bypass. Diabetes 2014;63:1725-37. http://dx.doi.org/10.2337/db13-1307

126. Martinussen C, Bojsen-Moller KN, Dirksen C, et al. Immediate enhancement of first-phase insulin secretion and unchanged glucose effectiveness in patients with type 2 diabetes after Roux-en-Y gastric bypass. Am J Physiol Endocrinol Metab 2015;308:E535-44. http://dx.doi.org/10.1152/ajpendo.00506.2014

127.Jorgensen NB, Dirksen C, Bojsen-Moller KN, et al. Exaggerated glucagon-like peptide 1 response is important for improved beta-cell function and glucose tolerance after Roux-en- $Y$ gastric bypass in patients with type 2 diabetes. Diabetes 2013;62:3044-52. http://dx.doi.org/10.2337/db13-0022

128. Jiménez A, Casamitjana R, Viaplana-Masclans J, Lacy A, Vidal J. GLP-1 action and glucose tolerance in subjects with remission of type 2 diabetes after gastric bypass surgery. Diabetes Care 2013;36:2062-9. http://dx.doi.org/10.2337/dc12-1535

129. Sjostrom L, Lindroos AK, Peltonen M, et al. Lifestyle, diabetes, and cardiovascular risk factors 10 years after bariatric surgery. $N$ Engl J Med 2004;351:2683-93. http://dx.doi.org/10.1056/NEJMoa035622

130.Buchwald H, Estok R, Fahrbach K, et al. Weight and type 2 diabetes after bariatric surgery: systematic review and meta-analysis. Am J Med 2009;122:248-56.e5. http://dx.doi.org/10.1016/j.amjmed.2008.09.041

131.Arterburn DE, Bogart A, Sherwood NE, et al. A multisite study of longterm remission and relapse of type 2 diabetes mellitus following gastric bypass. Obes Surg 2013;23:93-102. http://dx.doi.org/10.1007/s11695-012-0802-1

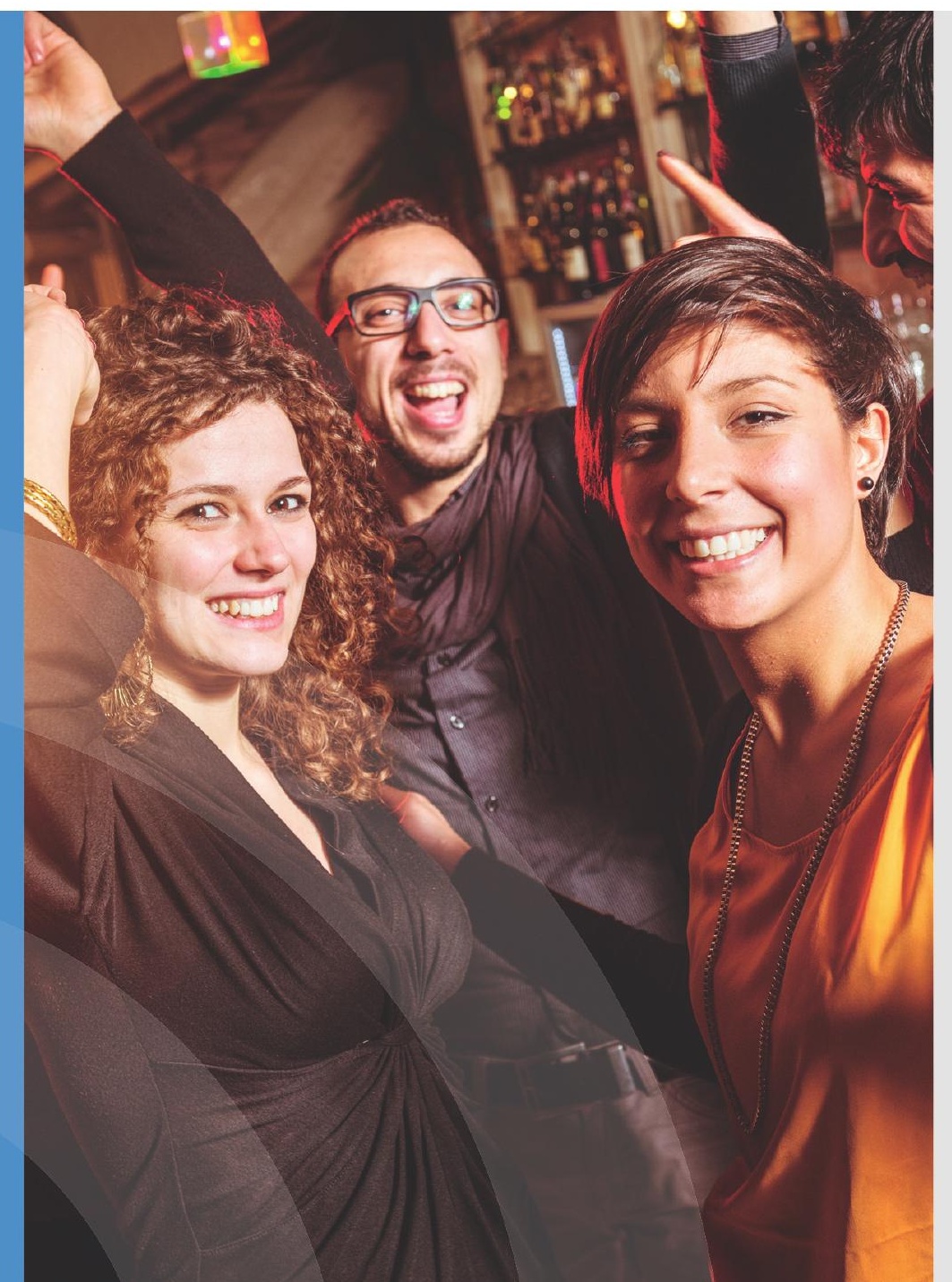

'Inuisibly' small goes very well
wifh your sfim dress...

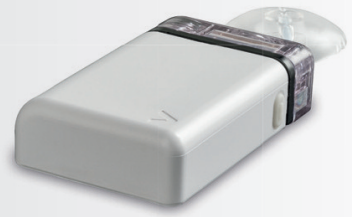

Diabetes is complicated enough.

Let's make it as simple as possible. 